Article

\title{
Investigating the Implications of the London Heathrow Airport Expansion for the Landside Freight Industry
}

\author{
Ryan Lee $^{1}$, Moayad Shammut ${ }^{2} \mathbb{D}$, Julian Allen ${ }^{3}$, Xing Gao ${ }^{4}$, Tianren Yang ${ }^{5,6}{ }^{\mathbb{D}}$ and Mengqiu Cao ${ }^{3, * \mathbb{D}}$ \\ 1 Ministry of Transport and Mining, Kingston 876, Jamaica; rlee@mtw.gov.jm \\ 2 School of People, Environment and Planning, Massey University, Palmerston North 4442, New Zealand; \\ m.shammut@massey.ac.nz \\ 3 School of Architecture and Cities, University of Westminster, London NW1 5LS, UK; allenj@westminster.ac.uk \\ 4 Bartlett School of Planning, University College London, London WC1H 0NN, UK; xing.gao@ucl.ac.uk \\ 5 Martin Centre for Architectural and Urban Studies, University of Cambridge, Cambridge CB2 1PX, UK; \\ ty290@cam.ac.uk \\ 6 Department of Urban Planning and Design, The University of Hong Kong, Hong Kong, China \\ * Correspondence: m.cao@westminster.ac.uk
}

check for

updates

Citation: Lee, R.; Shammut, M.; Allen, J.; Gao, X.; Yang, T.; Cao, M. Investigating the Implications of the London Heathrow Airport Expansion for the Landside Freight Industry. Logistics 2021, 5, 50. https://doi.org/ $10.3390 /$ logistics 5030050

Academic Editors: EunSu Lee,

Yongjang Kwon, Melanie McDonald and Yong-Shin Park

Received: 8 June 2021

Accepted: 7 July 2021

Published: 12 July 2021

Publisher's Note: MDPI stays neutral with regard to jurisdictional claims in published maps and institutional affiliations.

Copyright: (c) 2021 by the authors. Licensee MDPI, Basel, Switzerland. This article is an open access article distributed under the terms and conditions of the Creative Commons Attribution (CC BY) license (https:// creativecommons.org/licenses/by/ $4.0 /)$.

\begin{abstract}
The air cargo industry is hugely important to national economies, trade, and development. Thus far, there has been limited research on the landside freight industry. Therefore, the purpose of this paper is to extend the understanding of how alterations in the air cargo industry impact on its landside freight counterpart. It also seeks to explore the potential opportunities and challenges this presents, as well as the measures that can be taken to mitigate unsustainable development for the landside freight industry. Semi-structured interviews were used to collect the views of key stakeholders, freight industry experts, and other professionals. Our findings show that, if the airport expansion went ahead, the opportunities would generally outweigh the challenges. Increased freight activities and other positive spinoffs would result in the long-term. Increased freight activities and employment were the prime positive implications. Conversely, increased delays due to congestion was the main negative implication. Measures suggested to mitigate the adverse effects of the London Heathrow Airport (LHR) expansion entailed strengthening of consolidation centre efforts, freight collaboration, intelligent booking systems, use of low-carbon technologies, smart scheduling for revising the timetabling of deliveries, and greater use of rail transport for air cargo. The research highlights novel insights regarding existing freight-related issues from industry and academic experts, and further thoughts in relation to increased cargo activities stemming from the LHR expansion.
\end{abstract}

Keywords: logistics; freight transport; surface access; supply chain; air cargo; London Heathrow Airport expansion

\section{Introduction}

Investigating the implications for the landside freight industry due to the expansion of London Heathrow Airport is imperative given the huge contributions of the air cargo industry to national economies, trade, and development. In 2020, the Supreme Court's ruling lifted the ban on Heathrow's plans for a third runway on the grounds of the UK's commitment to tackling climate change [1]. The new runway (third), which is claimed to be vital to the UK, and is bolstered by Government support, encompasses the creation of a greater export capacity, world-class facilities, connections to new destinations, and more flights as part of an expansion project. Due to its scale, the proposed project is classed as a Nationally Significant Infrastructure Project under the 2008 Planning Act, it must still comply with the specific requirements of the Airports National Policy Statement and a range of wider planning policies at a local, regional, and national level [2]. Therefore, it is an opportune time to investigate the implications for the landside freight industry, which is integral to the supply chain and the wider economy. Studies regarding cargo 
or freight in the air transport industry have primarily focused on air side factors such as aircraft capacity and operations [3], with limited in-depth research relating to the land transportation of freight to the end user within the supply chain. In this paper, the air cargo industry refers to the actors who participate in and the infrastructure that supports the supply chain for air cargo. Air cargo includes freight commodities of all kinds, including small-package counter services, and express and priority reserved freight services. These are goods travelling through the airport for onward shipment, according to Heathrow Airport Limited (2018) [4]. The landside freight industry in this context also includes the stakeholders involved in the movement of air cargo on land within the supply chain community and the operations undertaken using the surface access modes of transport from the airport. The premise of the research relates to the supply chain on land, on which air cargo has a major influence.

As a result of the LHR dominance in the European region, the airport expansion case study was used to help understand how alterations in the air cargo industry would impact on its landside freight counterpart. London Heathrow was ranked nineteenth among the top 20 busiest airports for cargo handled worldwide, according to the Airports Council International (ACI) in 2020 [5]. This study provides valuable insights from the perspectives of industry and academic experts. It also contributes to the existing literature on air cargo in two ways. First, the paper bridges the research gap regarding the synergies between air cargo and related opportunities and activities within the supply chain on land. Secondly, it provides novel insights into existing freight-related issues and further thoughts on how to optimise the benefits of increased cargo activities whilst navigating the negative implications stemming from airport expansion, which are critical in terms of their effect on public support or opposition.

The paper is organised as follows: Section 2 reviews the existing literature on the pertinent topics. Section 3 describes the study area, the data used, and the analytical process followed to explore the implications of LHR expansion. Section 4 presents the results and Section 5 discusses the implications of the results, which covers the opportunities, challenges, and mitigation measures. Lastly, Section 6 draws conclusions and suggests policy implications.

\section{Literature Review}

\subsection{Air Cargo Industry}

The air cargo industry consists of many different types of companies [6]. The rationale behind it is that goods need to be transported to the airport for use within the airport, in particular food and drink for onsite catering, and materials to service aircraft such as parts and equipment. Some airlines operate dedicated freighter aircraft while others simultaneously carry passengers and freight together $[7,8]$. The former is known as pure cargo and the second as belly-hold cargo as cargo is carried in the hold (the belly) of passenger flights. Most cargo travels in the belly hold of passenger aircraft, while only a handful of dedicated freighter flights operate each week from LHR.

The most well-known companies are the integrators, such as FedEx, UPS, TNT, and DHL Express, who provide customers with a door-to-door service mainly for time-sensitive and relatively small shipments [9]. The integrators own large fleets of aircraft devoted entirely to the carriage of air cargo and own or work with trucking companies to pick up and drop off shipments, to transport cargo to its destination and to carry packages that are not particularly time sensitive. Another option that is sometimes used, according to Wensveen (2015) [10], involves the coordination of rail and truck transportation by the freight forwarder. Older studies [11] concur that freight forwarders, third-party logistics providers (3PL) specialising in air cargo services, and manufacturers in those industries frequently use air transportation. Other services that support the aforementioned companies on a 24-h basis include accessibility to customs and brokers, fuelling and maintenance services, and adequate apron space and lighting for cargo handling and aircraft maintenance. 
Ground transport characteristics, such as the highway infrastructure, are important to trucking companies and to integrate or express carriers who provide a complete doorto-door service, including air transport, ground pickup, and delivery [11]. Having good links to an uncongested road network has become increasingly important to meet fast overnight delivery targets according to Gritschke (1999) [12] and the Department of the Environment, Transport, and the Regions (DETR) (2000) [13]. Good road access has also received significant attention, with airports promoting themselves as cargo gateways [14]. For instance, Manchester Airport promotes its superb position at the strategic centre of the UK motorway network and the fact that $60 \%$ of the UK's manufacturing capacity lies within a 2-hour truck drive of the airport.

However, airports may not always be in control of the surface access infrastructure, although it has a huge impact on them [15]. For example, at LHR the roads are owned by the Highways Agency and local authorities, the train companies operate the train services while Network Rail looks after the rail infrastructure, and the bus and coach companies provide the bus services.

\subsection{LHR Expansion Debate on Implications}

Several academic studies have debated the feasibility of the LHR expansion from political, economic, and environmental perspectives [16-19]. Griggs and Howarth [20] highlighted the different strategies used by UK political parties and lobby groups over the last 60 years to promote or oppose the airport expansion [19]. These authors' arguments boiled down to two main strands: The negative implications for the environment, and the opportunities for economic growth. Further to the study by Griggs and Howarth [20], this paper asserts that LHR expansion will lead to an increase in air cargo operations and hence a range of significant implications. Within the context of LHR expansion, expanded air cargo would translate into an increase in the quantities of the aforementioned commodities, potentially ramping up the demand for freight companies and transport infrastructure.

\subsection{Positive Implications of the Air Cargo Industry}

The air cargo industry makes a wide range of contributions to an economy. Airfreight for instance, is a premium service [10]. Superior service adds value to any product and generates a quality image for the shipper projecting the idea of a premium product and company progressiveness. Airfreight can also add a new competitive edge to a company's marketing strategy, stimulate growth in existing markets, and allow companies to enter new markets without making a commitment to large, fixed investments in warehousing and inventories [10]. In 2010, Steer Davies Gleave (SDG) estimated that airfreight services directly generate around GBP 2 billion in terms of Gross Value Added (GVA) and around 39,100 jobs [21]. In addition, through its supply chain (indirect effects) and through the expenditure on incomes earned as a result of direct and supply chain activities (induced effects) $[2,22,23]$, airfreight services support a significant proportion of GVA and employment. SDG estimated the total economic footprint of the sector (direct, indirect, and induced effects) to be around GBP 7.3 billion in GVA and 135,300 jobs [21].

Air cargo operations also generate additional revenue for airports, as well as the surrounding community, and provide better utilisation of airport facilities since many of these services are conducted during off-hours (midnight to 6 a.m.) [24]. Although it is difficult to effectively quantify the impact of the sector on the wider economy, using a multiplier analysis based on the UK input-output tables, SDG produced an estimate of what it termed 'forward linkage effects' on the economy. Perhaps, then, it can be argued that, as opportunities are multiplied for these freight operations, this in turn can strengthen the industry and provide far-reaching benefits for communities.

\subsection{Negative Implications of the Air Cargo Industry}

Challenges within the air cargo industry may come from the airport itself or from outside. The location of a freight company may limit how much it can spatially expand. A 
few companies have had plans for expansion or alteration of their premises rejected due to the proximity of LHR and the possibility of their causing interference with airport radar and navigation aids [16]. The study by Hoare (1974) [16] also found that companies' staff time was taken up with meeting and entertaining visitors for purposes beyond their job role due to their location en route to the airport.

As things stand, capacity is a key challenge at LHR. Many of the largest airports are facing major congestion issues with air and ground operations given that there is aggressive competition to try to capture a substantial share of the increased air cargo volume [24]. Janic (2004) [25] explored the long-term capacity demand at LHR using different scenarios. Even with a plethora of scenarios, there were no easy fixes to address this capacity problem in regards to air transportation, an issue experienced by both the air and land domains at airports. Trying to tackle airport capacity challenges with timing mechanisms also proved problematic. Airport slot auctions [26], for example, have serious defects, both in terms of generating increased competition for airlines and making more efficient use of scarce airport capacity, and the practical problems that could result [27]. Although it can only address air side capacity issues, revised time tabling may be considered as a means of alleviating surface access capacity constraints.

Furthermore, airports with infrastructures that are less constrained by growth regulations offer greater value, since they are in a better position to exercise the growth options available in the airport industry [28]. Sankaran (2000) [29] also identified transport regulations as one vital factor that influences logistics practices in New Zealand. In the case of LHR, there are existing night restrictions on operations [30], which are compounded by stipulations from environmental regulations [15]. Typically, these environmental concerns relate to atmospheric pollution from vehicle emissions [31-33], as well as localised noise and visual intrusion [34,35]. Road-based trips (especially private car trips) were observed to generate the greatest share of surface access emissions. In 2005, road-based journeys accounted for $91 \%$ of airport access emissions in the UK [36]. The road traffic generated by LHR has resulted in the area of West London around the airport having air quality which is among the worst in the city. This has led to increased political pressure for airports to reduce the proportion of journeys made by private car and increase access by public transport. Delivery delays caused by airport-generated road traffic is another challenge for the air cargo industry. Information from Heathrow Airport Limited (2018) [2] indicates that congestion and delays on the transport network are bad for the economy, as road traffic congestion was estimated to have cost the UK economy about GBP 31 billion in 2016 through lost time and unreliable journeys.

Activities relating to the air cargo industry also have adverse impacts on surrounding communities and thus pose a challenge. For example, freight movements can cause problems for local people including vehicles using inappropriate routes, parking in residential areas, and associated anti-social behaviour and nuisance such as dumping rubbish [2]. Community lobby groups have exerted political pressure, resulting in the creation or enforcement of additional regulations to restrict the freight operations, which may negatively affect the industry. Another challenge for the freight industry relates to labour competition between the airports and companies located in the surrounding communities for higher wages [16]. The common view is that this acts as a drain on labour, particularly in the manufacturing sector. Compared to the noise and labour problems, other disadvantages cited by companies are of minor significance [16].

Table 1 provides a simplified list of the positive and negative implications of air cargo. 
Table 1. Breakdown of implications of the air cargo industry (Source: The authors based on review of literature).

\begin{tabular}{|c|c|}
\hline Positive & Negative \\
\hline 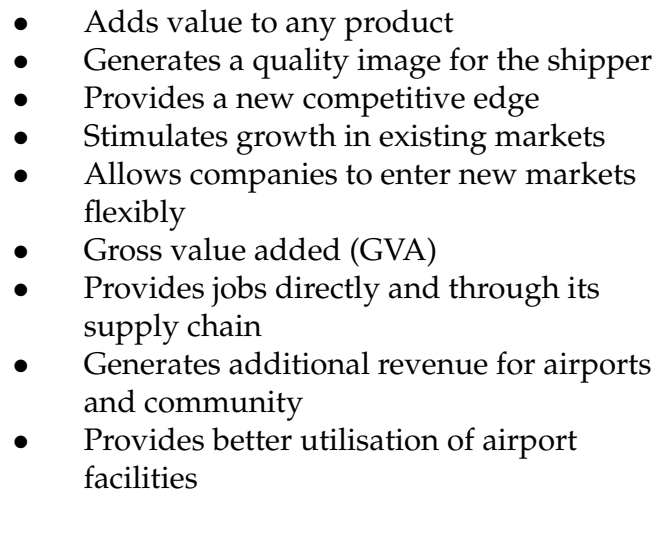 & $\begin{array}{l}\text { - } \quad \begin{array}{l}\text { Restricts expansion or spatial alteration of } \\
\text { other nearby premises }\end{array} \\
\text { - } \quad \text { Capacity problem for air and ground } \\
\text { operations, and increased congestion } \\
\text { Delivery delays through lost time and } \\
\text { unreliable journeys } \\
\text { Environmental concerns (atmospheric } \\
\text { pollution) and nuisance such as dumping } \\
\text { rubbish } \\
\text { - Increases political pressure on airports } \\
\text { - } \quad \text { Vehicles use inappropriate routes and } \\
\text { - } \quad \text { Acts as a drain on labour for other } \\
\text { employers }\end{array}$ \\
\hline
\end{tabular}

\subsection{Mitigation Measures}

In light of the challenges faced by the freight industry, Sustainable Urban Freight Transport (SUFT) may offer an appropriate means of tackling the adverse impacts on land freight, as described by Behrends et al. (2008) [37]. The SUFT approach is comprehensive and may yield beneficial outcomes in terms of addressing the aforementioned problems. Behrends et al. (2008) [37] further pointed out that most of the negative impacts of freight transport occur at the traffic system level whereby vehicles consume energy and produce emissions. The consigner and consignee determine the demand, the freight forwarder determines the traffic, and the transport operator determines the technical capability. The claim by Behrend et al. (2008) [37] helps explain why two dedicated consolidation centres for storage and materials handling were established by the British Airport Authority in the early 2000s close to the main site at Colnbrook and Heathrow South to support Just In Time (JIT) logistics operations [38-40]. These consolidation centres eventually became compulsory for retail and construction logistic operations to alleviate congestion within airports, reduce vehicle movement, and improve security and waste management, among other economies of scale benefits [41]. However, Nguyen et al. (2014) [42] pointed out that a freight consolidation problem might exist in the case of perishable products where there is a hard time constraint on the product's stay in inventory at the consolidation centre. Therefore, special arrangements are necessary when dealing with perishables and the required storage for subsequent distribution.

It is also clear that the actors involved are not just limited to their own area in terms of contributing to sustainable development. By setting requirements, they can influence the actions of the other actors downstream in the causal chain. City authorities and planning agencies can influence all these sectors, and thus play an important role in designing sustainable development strategies [37]. Therefore, an integrated approach that involves all the actors in collaborative decision-making within the supply chain management $[43,44]$ is necessary to overcome the challenges that exist within the industry. Zhu et al. (2021) [45] suggested that the integration of information gives firms a competitive advantage, while eliminating information delay helps the supply chain to perform more efficiently.

Connectivity is another mitigation measure used within the freight industry [46]. This fits perfectly with infrastructure improvement in the vicinity of the airport. Behiri et al. (2018) [47] highlighted the importance of scheduling goods transport using passenger trains. These measures are designed to mitigate the adverse impacts primarily associated with road transport rather than rail transport. However, this is salient given that road transport is the predominant method used for landside freight operations. Finally, Tang and Veelenturf (2019) [48] claimed that leveraging new technologies can have a significant effect on market competitiveness. Companies that are able to develop cyber-physical 
systems can utilise techniques such as additive manufacturing, advanced robotics, artificial intelligence, autonomous vehicles, blockchain [49-52], drones, the internet of things, etc. to create economic, environmental, and social values. However, given that many of these technologies are still unproven, they may create other problems such as job losses due to automation and social inequality.

\section{Study Area, Data, and Methods}

\subsection{Study Area}

London Heathrow Airport (LHR) is located to the west of central London, near the southern end of the London Borough of Hillingdon. As well as LHR, there are several other airports, such as Gatwick, Luton, Stansted, and Manchester Airport, which currently handle air cargo in the UK. However, LHR was chosen as a suitable case study for several reasons.

First, the UK economy depends on air cargo, and LHR is at the heart of that industry. LHR is a major freight hub and is the largest freight port by value, transporting more than Felixstowe, Southampton, and Liverpool combined. For example, LHR handles 32\% of all UK goods by value (GBP 107 billion) and 70\% of the UK's total air-cargo trade [13,53]. In addition, statistics from the UK Civil Aviation Authority (UK CAA 2020) [54] showed that in 2019, the main London airports handled around 1.96 million tonnes of freight, with Heathrow Airport accounting for approximately 1.59 million tonnes. The only other significant player in the London market was Stansted Airport, which handled around 0.22 million tonnes, with Gatwick Airport handling around 0.11 million tonnes. Therefore, LHR has the most significant impact on the UK's landside freight industry due to the amount and value of freight that it handles. Second, the airport offers the largest range of long-haul destinations out of all the London airports and has by far the greatest aircraft capacity. Each year, the airport handles more than 1.5 million tonnes of cargo [4]. Third, LHR is well placed to take advantage of the strategic road network. It serves as an integrated transport hub since it brings together road, rail, and air transport. Finally, LHR offers an ideal, contemporary site from which to collect a wide pool of data with which to analyse the implications for the landside freight industry. A graphical display of the surface access connectivity at LHR can be seen in Figure 1.

\subsection{Data and Methods}

Following the approach by Kelley et al. (2003) [55], semi-structured interviews were used to collect the views of key stakeholders, freight industry experts, and other professionals. The interview questions were based on broad themes related to the research topic. Each in-depth interview lasted between 45 and $90 \mathrm{~min}$, and the analysis of the interview findings was undertaken between July and August 2018. The themes covered in the interview questions included LHR expansion, air cargo, rail and road surface access modes, freight operation partners, opportunities, challenges, and mitigation measures. Interviewees were asked to identify what they perceived to be existing opportunities, challenges, and mitigation measures for the freight industry. In addition, they were asked to provide their views on the implications of the LHR expansion and rank them in order of importance, using the approach adapted from the study by Cao et al. (2017) [32]. A simplified overview of the methodology can be seen in the Data Flow Chart shown in Figure 2. 


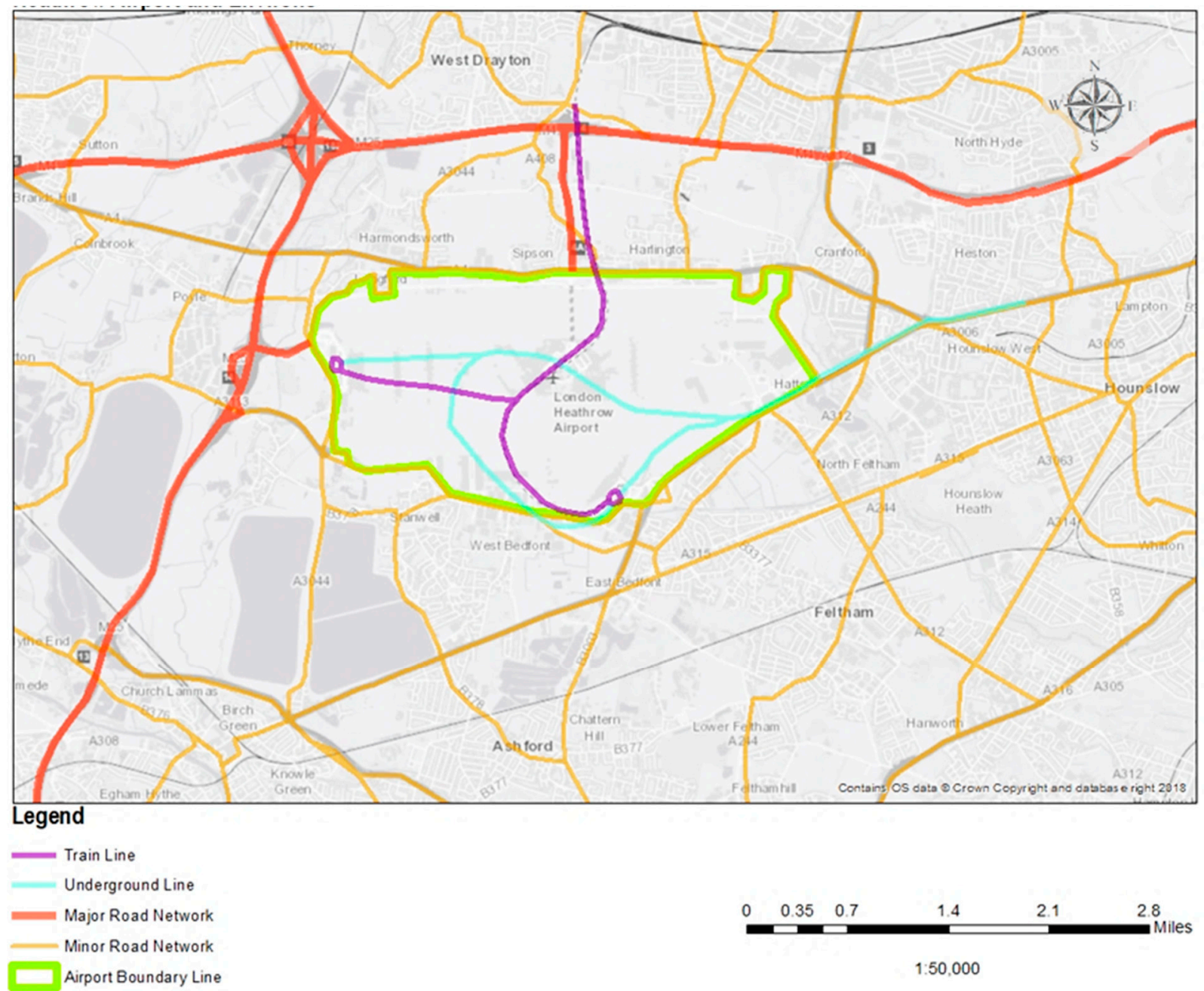

Figure 1. Map of Heathrow airport surface access connectivity and environs. (Source: Adapted from the online OSM 2018).

Initially, over thirty prospective interviewees, including representatives from Heathrow Airport Limited and academics from UK universities, were contacted to ask if they would like to participate in the study. Twelve participants eventually accepted the invitations and were interviewed, which limited the robustness of the analysis. Nonetheless, these interviewees held senior positions in their respective organisations and all had at least 15 years' experience within the freight, logistics, and/or transport fields. Before the interview, each participant was sent a copy of the interview questions by email, thus enabling them to prepare for the interview. Interviews were undertaken with representatives from freight industry companies, freight and logistics experts, transport planners and consultants, as well as academics. A breakdown of the coded format used to identify the experts who participated in the interviews is shown in Table 2.

The freight-related companies were approached since they have valuable knowledge and experience regarding the impacts of the LHR expansion and any potential mitigating measures. The freight and logistics experts were able to offer knowledge about how to maximise supply chain efficiency, as well as expertise in logistics planning. Additionally, the transport planners and consultants could offer valuable advice on planning the infrastructure facilities for the movement of people, goods, and services. Contributions from academics were also sought in order to ascertain their views regarding the topic.

The qualitative analysis software 'NVivo 12 ', was used to assist with the thematic coding of the data. This software has been used by several researchers to conduct qualitative research [56,57]. Once each interview had been transcribed and verified, thematic coding of the data was undertaken to allow the findings to be analysed. After the data had been 
thematically coded, the next step involved trying to identify the key themes and ideas expressed by all three groups for further analysis.

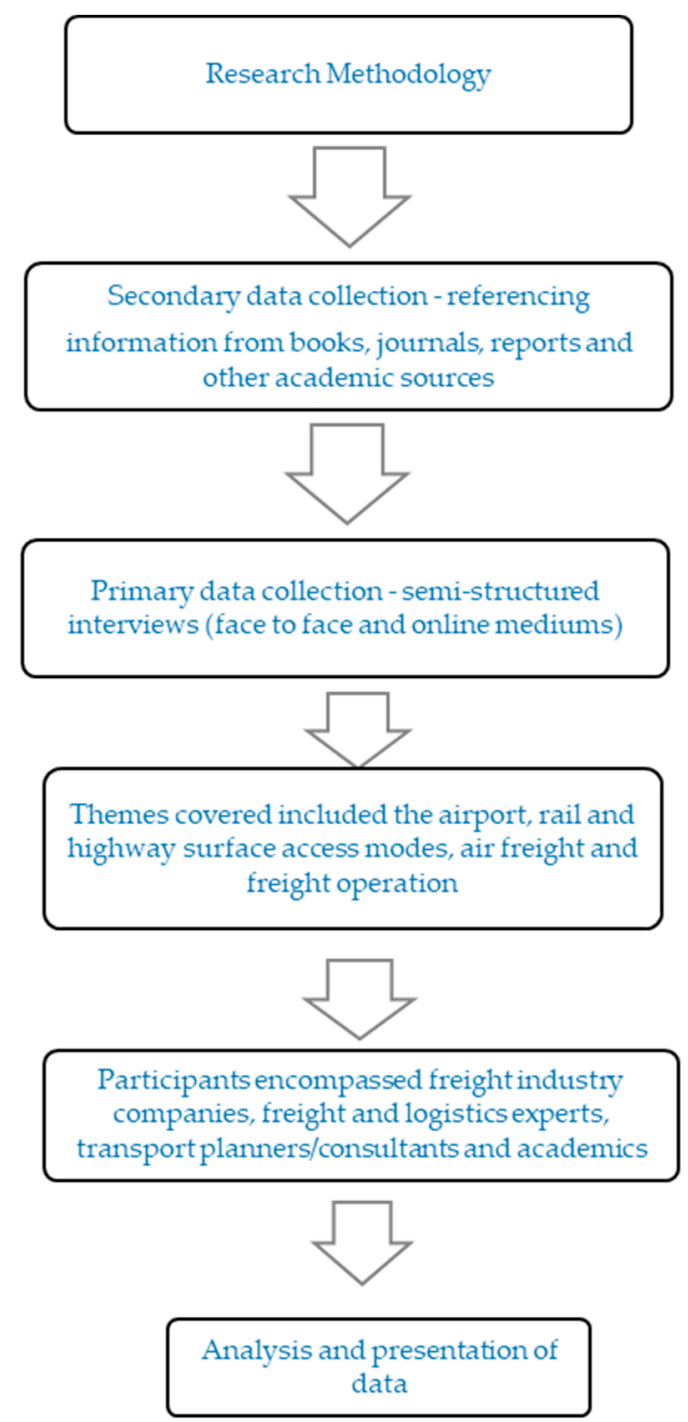

Figure 2. Data flow chart of methodology.

Table 2. Coding used for interview candidates.

\begin{tabular}{cccc}
\hline Category & Organisation & Gender & Code \\
\hline & & Male & A1 \\
(A) Freight Industry & Freight-related Companies & Male & A2 \\
& & Male & A3 \\
& & Male & Male \\
\hline \multirow{2}{*}{ (B) Freight and } & Transport for London & Male & B2 \\
Logistics Experts, & Transport Systems Catapult & Female & B3 \\
Transport Planners, & Transport Systems Catapult & Male & B4 \\
and Consultants & Buckinghamshire County Council & Male & B5 \\
& Pumshire County Council & Male & B6 \\
\hline \multirow{2}{*}{ (C) Academics } & University of Westminster & Male & C1 \\
& University College London & Female & C2 \\
\hline
\end{tabular}




\section{Results}

This section presents the results in relation to: Air cargo at LHR, types of companies, and rail and highway modes of transport. It also discusses the effects of changes within the air cargo industry on its land freight counterpart. These include freight operation partnerships, opportunities, challenges, and mitigation measures.

\subsection{Types of Air Cargo at LHR}

The first research theme analysed relates to the different types of freight dealt with at LHR. Specific commodities were identified, as well as more general categories to describe the types of air cargo that were handled at LHR. For instance, when asked, what types of freight do you think are handled by LHR, one academic responded that a major hub such as Heathrow handles almost every kind of freight with most of it comprising commercial products and produce, as well as some perishables, animals, dangerous goods, materials and parts, etc. 'Dangerous goods' refer to flammable or harmful substances such as gases, oxidisers, poisons, corrosives, and hazardous biological or chemical material [58].

The results evidenced that the scope of freight handled at LHR is vast, and the types of freight range from pallets of medical apparatus in one shipment, to live pet transportation in the next or from standardised cartons of clothing being imported, to hazardous material classed as dangerous goods requiring professional handling, such as batteries or nail polish remover. Airmail and parcels were also repeatedly mentioned throughout the various interviews. Only one expert mentioned pharmaceutical supplies or 'pharma' as one type of freight handled at LHR. The interviews gave little indication of how the airport expansion would influence the dynamics involved in the type of freight handled. However, a company may choose to handle certain types of freight via LHR based on the level of profitability that can be achieved from those specific types of commodities.

\subsubsection{Companies Involved in the LHR Air Cargo Industry}

Companies involved in the air cargo industry at LHR were the second research theme analysed. It was found that the movement of cargo brings together airlines that carry the cargo, freight handling companies who book in and research or co-load cargo for the airlines, and freight forwarders who arrange with importers and exporters for the cargo to be transported. The one thing that brings them all together is the movement of cargo. When asked to outline the types of companies that they thought engaged in freight business at LHR, the participants identified a range of companies, including freight forwarders, haulers, insurers, security companies, airlines, and even retailers. Notably, the interviewees repeatedly mentioned parcel delivery and mail companies such as DHL.

Handling air cargo and mail accounts for almost 70\% of surface access operations at LHR explains why mail companies were foremost in the interviewees' minds. Statistics published by the UK CAA (2021) [54] indicate that, of the total tonnage handled at the airport from 2015 to 2020 the percentage split between cargo and mail remained at 95\% and $5 \%$, respectively. Table 3 shows the type of freight and logistics services required at LHR.

Table 3. Freight and logistics services at Heathrow Airport-surface access modes in 2018 (Source: Adapted from Heathrow Airport Limited (2018) [2]).

\begin{tabular}{ccc}
\hline Freight and Logistics Services & Vehicles per Day & Percentage (\%) \\
\hline Handling air cargo and mail & 9000 & $69 \%$ \\
Servicing the airport & 1500 & $12 \%$ \\
Servicing the aircraft & 2500 & $19 \%$ \\
\hline
\end{tabular}

The literature suggests that DHL or express mail companies, who act as integrators by providing door to door deliveries, are predominant [6]. These companies offer a "one stop shop" which caters for the full range of services from the origin to the end point of journeys, 
including transport, insurance (security), and fast delivery time benefits for customers. This makes them popular with clients.

\subsubsection{Surface Access Needs}

Surface access needs at LHR were the third theme analysed. Road transport was the primary mode used for freight movement at LHR according to the interviewees. However, the freight and logistics experts suggested that not enough was being done to fully utilise the potential of existing rail transport at the airport. Similarly, the literature confirms that airlines have instituted trucking services to expedite deliveries for the end-to-end distribution of freight to customers [11,24,30,59]. Information from LHR also affirmed that, currently, most airport-related goods are transported by road with some use of rail freight, particularly in the construction industry and for aircraft fuel [2]. Additionally, the literature supports the idea that good road access to airports is clearly an important issue when deciding where to locate all types of cargo services $[11,13,14,60]$. Road transport is further recognised as offering clients a less expensive form of freight transport. However, rail transport is considered the better transport option for moving heavy and bulky goods from one point to another.

\subsection{Implications for the Landside Freight Industry}

The fourth theme analysed for the study was the implications of the freight operations for the supply chain on land. These implications encompassed opportunities and challenges, which refer to the positive and negative implications, respectively. A breakdown of the results regarding implications and how they could be mitigated is shown in Table 4, with a more detailed discussion provided in the subsequent sections.

Table 4. Breakdown of implications and possible mitigation measures (Source: The authors based on data analysis).

\begin{tabular}{|c|c|c|c|}
\hline \multirow{11}{*}{ Direct Implications } & Opportunities & Challenges & Mitigation Measures \\
\hline & Increase in freight traffic & Insufficient space & Expansion of capacity \\
\hline & Greater Capacity & Competition & Collaboration between stakeholders \\
\hline & Demand for more housing & Rising cost of property & Information sharing \\
\hline & Positive economic effects & Regulations (emissions, etc.) & $\begin{array}{l}\text { Cleaner vehicles, airline fuel } \\
\text { improvements }\end{array}$ \\
\hline & $\begin{array}{l}\text { Test bed for new transport } \\
\text { technologies }\end{array}$ & $\begin{array}{l}\text { Operating costs (labour, fuel, } \\
\text { and new vehicles) }\end{array}$ & $\begin{array}{l}\text { Use of consolidation centres } \\
\text { Restrictions on engine idling }\end{array}$ \\
\hline & GVA benefits & Congestion & Develop cargo only roads or routes \\
\hline & $\begin{array}{l}\text { Increased utilisation of } \\
\text { infrastructure }\end{array}$ & $\begin{array}{l}\text { Need to relocate current } \\
\text { facilities }\end{array}$ & Intelligent booking systems \\
\hline & $\begin{array}{l}\text { Increase in demand for road and } \\
\text { rail space }\end{array}$ & Security and delivery times & $\begin{array}{c}\text { Network connectivity (airport and } \\
\text { national infrastructure) }\end{array}$ \\
\hline & Employment & Rising cost of property & Smart scheduling of deliveries \\
\hline & Economies of scale & Lack of rail infrastructure & \\
\hline \multirow{4}{*}{$\begin{array}{l}\text { Induced } \\
\text { Implications }\end{array}$} & Jobs & Congestion & $\begin{array}{c}\text { Greater use of rail transport for air } \\
\text { freight }\end{array}$ \\
\hline & Quicker access to supply chain & Reduced road safety & $\begin{array}{l}\text { Weight restrictions on local } \\
\text { residential roads }\end{array}$ \\
\hline & $\begin{array}{c}\text { Good community facilities and } \\
\text { transport links }\end{array}$ & $\begin{array}{l}\text { Pollution (noise, emissions, } \\
\text { and waste) }\end{array}$ & $\begin{array}{l}\text { Explore alternatives such as river } \\
\text { freight or autonomous vehicles }\end{array}$ \\
\hline & & Lorry parking in communities & Assemble products onsite \\
\hline
\end{tabular}




\subsubsection{Opportunities within the Freight Industry}

The results show that the creation of employment opportunities and economic growth are positive outcomes stemming directly from freight operations at LHR. Furthermore, with reference to the LHR expansion, increased freight activities stood out as the predominant positive implication for the landside. Interviewees from the freight companies and transport planning, freight and logistics groups indicated that greater capacity and increased utilisation of the infrastructure were notable opportunities.

The freight companies, in particular, thought that the LHR expansion would generate more opportunities than challenges as road freight to LHR is expected to be increased. Consequently, there would be more deliveries from a larger volume of flights with freight being transported in the belly-holds. An expanded airport would also incentivise actors in the freight industry to form partnerships with LHR to plan operations strategically to reduce lead time, enabling fast deliveries at the right price.

The transport planning, freight and logistics group offered diverse views regarding the expanded opportunities for companies to consolidate deliveries, and create economies of scale, and the greater justification for having more rail freight interchanges and distribution centres located in and around the airport. Interviewees from the freight and logistics and academic groups expressed the view that, even though short-to-medium term disruption during the construction phase is expected, the growth of the air freight sector would be likely to translate into more jobs, depending on the level of automation that this would entail.

\subsubsection{Challenges within the Freight Industry}

The interview results affirmed that there are various direct and existing challenges. Existing challenges cited in the interviews included delays due to congested terminals and networks, labour force demand, poor connectivity between the airport transport network and the national network, time constraints including limited night operations, regulations, supply chain inefficiency, a lack of data sharing, and parking constraints. Primarily, congestion-related issues, greater competition, increased operating costs, and even legislative bottlenecks are likely to still exist as a result of the LHR expansion. The challenge identified as being most significant varied considerably across groups. For instance, interviewees from the freight companies' group gave various responses when asked about the challenges resulting from the LHR expansion and their further thoughts on this. One freight company employee cited competition from other freight companies that have a better economy of scale as the most important challenge, and regulations as the second most important challenge. Another interviewee from the freight companies' group thought that the limited capacity leading to higher prices compared to other European airports and slots would represent the most significant challenge, as freight companies were already struggling to stay in the vicinity of LHR. His second concern was the rapidly rising cost of property in the local area.

Interviewees from the transport planning, freight and logistics group further identified challenges in relation to security, labour shortages, regulations, expenses, and technological problems. The dominance of an oligopoly allegedly affecting the quality of service and efficiency was a challenge identified by one transport consultant where small companies were observed to be actively competing with larger companies and were more efficient. Meanwhile, another transport consultant pointed out that the expansion would have a detrimental effect on rail freight at LHR. However, given that rail transport appears to be more closely linked to ocean freight, it seems unlikely that the LHR expansion would cause any significant harm to the rail freight system.

The results further highlighted challenges derived from cause and effect. For example, an increase in demand for road and rail space would contribute to congestion, while a lack of rail infrastructure or connectivity would further compound this issue. Meanwhile, high levels of competition in a saturated market would affect the cost of sending freight via Heathrow. Another example is that competition and congestion due to limited 
capacity were perceived as the main challenges by the transport planning, freight and logistics group.

Generally, the academic group expressed similar views to the other groups regarding the challenges for the landside freight industry. The academics expressed concerns about capacity, access, and the impacts on the local population if potentially increased costs were passed on from LHR to airport users.

\subsubsection{Mitigation Measures for the Landside Freight Industry}

The measures suggested by the interviewees to help mitigate the adverse effects of the LHR expansion for landside freight companies were wide-ranging. The results showcased common opinions at the local and international levels, as well as innovative ideas in response to the question: What measures would you propose to alleviate the adverse impacts on the landside freight industry as a result of the earmarked expansion? The interviewees were also asked to rank them in order starting with the most important. For example, one freight company interviewee stated that his first-choice mitigation measure would be to expand the handling sheds' capacity. The second and third most important measures, in his opinion, would be to improve the roads, and Information and Communications Technology (ICT), respectively. Another member of the freight companies group described the potential rail connections between UK airports or between an airport and a seaport or a north-south rail link, which freight companies could use to reduce the volume of road haulage traffic, with additional possibilities for overseas expansion to France.

Further measures suggested helping the freight industry tackle both existing and future challenges, as cited by a transport planner encompassed exploring river freight, the use of freight collaboration, smart scheduling for revising the timetabling of deliveries, intelligent booking systems, and consolidation centres, which would involve establishing a depot on the M25. However, the nature of JIT, for example, whereby deliveries are often made at night but only taken in during the day, has already predicated the establishment of consolidation centres at LHR. Consolidation centres became mandatory for logistics operations in the construction and retail sector. Therefore, the concept of compulsory use of consolidation centres could be further expanded to other types of air freight with strategic consideration for perishable commodities. Another transport planner and a freight and logistics expert suggested that the LHR expansion itself presented an opportunity for mitigating challenges, whereby new technologies could be unlocked and applied within the landside freight industry:

"The first mitigation measure that comes to mind is to use the expansion of the airport as a test bed for new technologies-including low emission lorries. Additionally, to use electric vehicle (EV) technology and new apps to identify ways innovation could improve the supply-chain experience." (B4, male. 23 /7/2018)

The academic group also proposed vital additions to the mitigation measures for the landside freight industry. Land value capture techniques were suggested to provide a means of maintaining or improving local transport and local residential areas. S106 legal agreements were suggested to help alleviate problems caused to local communities, which are often affected by freight-related operations.

\subsection{Implications for Nearby Communities}

Spinoffs from freight operations can make or break the landside freight industry. These impacts are referred to as induced implications where the local communities and environs come into play. Local communities do have some power to influence the longevity of the ongoing freight operations and several lobby groups have been contesting the genesis of the airport expansion proposal. Therefore, establishing good relationships with local communities can help strengthen the freight industry [22,24]. Labour force demand created by freight operations satisfies both community members and the freight companies. This partnership provides opportunities and is one reason why many residents tend to favour freight operations in their neighbourhood. Conversely, if freight activities 
destroy adjacent communities, residents are likely to resist these operations, resulting in undesirable repercussions for the industry.

\subsubsection{Community Opportunities}

The results revealed several positive impacts for the nearby communities due to LHR freight operations. It was found that employment opportunities were the most frequently mentioned benefit for communities. This was a common view across all the groups interviewed. Quicker access to logistics services for local businesses, cheaper costs of shipping, and demand for more housing developments in the area to facilitate residential growth were other novel opportunities mentioned in the interviews. Novel opportunities, namely, access to faster lead times on goods for customers, and cheaper costs of shipping were suggested. It seems likely that these benefits would be multiplied due to the LHR expansion.

\subsubsection{Challenges for Nearby Communities and Mitigating Measures}

Despite the opportunities described above, the communities near LHR faced several challenges. Interviewees from the freight companies, transport planning, freight and logistics and academic groups provided similar views regarding these challenges. Congestion and environmental-related impacts were cited as major issues. The environmental-related impacts included air pollution, noise, congestion, and waste disposal challenges both during the daytime and at night, and these problems may be exacerbated by congestion. Other challenges included parking concerns, the strain on the transport infrastructure of moving freight, an increase in road traffic accidents and personal car use, as well as the potential bad press for companies. It is anticipated that these challenges will grow as a result of the LHR expansion. However, relevant measures can be implemented to alleviate the difficulties.

An academic interviewee suggested two mitigation measures when asked the question, what challenges do you think the surrounding communities experience due to freight operations in the area and explain how any adverse impact could be mitigated.

"There are issues around the routeing of heavy goods vehicles (HGVs) through residential areas and lorry parking problems overnight in residential areas with the litter and other problems. Additionally, there is congestion in and around the area, as the majority of transhipped freight by road need to access the motorway network at existing road junctions. The impacts could be mitigated by weight restrictions on local residential roads to prevent HGVs using residential areas as cut throughs and rat runs. Prevent deliveries during the morning and evening peaks to prevent freight vehicles adding to the already constrained motorway network during peak times." (C2, female. 25 /7/2018)

One transport planner specifically mentioned that assembling products onsite could help mitigate the adverse impacts. However, manufacturing products on site might overburden the waste management and waste disposal system of these assembly plants. This could potentially result in trickle down pollutants affecting the nearby communities. Alternatively, one freight and logistics expert suggested that modern technology could play a role in mitigating congestion through the use of intelligent booking systems that are able to incorporate Artificial Intelligence (AI), machine learning to allow greater efficiency and improved productivity, as well as using consolidation centres located near the airport that feed the city centre to minimise pollution.

Additionally, an interviewee from the freight companies group pointed out that two of the main challenges for communities-traffic and pollution-could be mitigated by developing cargo only roads or routes and using cleaner vehicles, restrictions on engine idling, and improvements to airline fuel. Additional mitigation measures suggested by the freight companies group included the development of a coherent strategy to improve the road and rail infrastructure, lobbying for funding commitments from Network Rail, Highways England and their counterpart companies to improve the connectivity of rail 
and roads in the region, as well as helping expand freight terminals, sharing of data, greater specialisation, and relocation.

\section{Discussion}

In this section, the findings regarding the implications of LHR expansion are analysed and discussed in detail. Increased freight activities were rated as the predominant positive implication for the landside freight industry by the group of interviewees. While opportunities within the freight industry, such as employment generation, economies of scale, and economic growth, were similar to those identified in the literature review $[7,10,22,23,61]$, new suggestions also emerged, namely greater demand for rail freight interchanges and distribution centres in and around the airport. Arguably, diversifying the modes by which freight is moved would be beneficial and could generate ripple-effect opportunities with the potential to reduce the strain on the road infrastructure. There were also further opportunities for nearby communities in terms of quicker access to logistics services for local businesses, cheaper costs of shipping, and the facilitation of residential growth. These positive impacts may also generate multiplier effects.

There were mixed views regarding the most significant challenge and all three groups sometimes drew links between the various challenges faced. For example, a limited capacity was regarded as a factor that would increase congestion. There was concurrence that congestion at LHR is compounded by the limited capacity both within the airport and on the national road networks. Importantly, tackling congestion with a view to alleviating the impacts on the surrounding environs, is one key objective of the LHR expansion plan. Constrained capacity and competition were also perceived as significant challenges for freight companies. Similarly, the literature review indicated that many of the UK's largest airports are facing major congestion issues with air and ground operations, which are costly $[16,24,34,35]$. Novel challenges that arose from the findings included potential bad press for companies and excessive dependence on the road infrastructure to move freight.

Overall, it was found that the challenges to surrounding communities mentioned by the interviewees were consistent with previous studies $[15,35,36]$. In addition, the results corresponded with the Heathrow Airport Limited (2018) [2] statement that there were social, environmental, and road safety concerns for communities impacted by freight operations at LHR. More emphasis was placed on discussing the adverse impacts of road transport, while the effects of rail transport were downplayed. The LHR expansion could cause increased delays, as well as exacerbating noise pollution, reducing air quality, and posing other challenges. These are likely to be a source of frustration for local communities and thus might cause lobby groups to pressure political leaders towards anti-expansion campaigns.

The findings regarding mitigation measures primarily focused on challenges relating to road transport and this is consistent with the literature. We concur that road transport is the primary means used by LHR freight companies for landside movement. This potentially causes more wear and tear on the infrastructure, given the greater volume and frequency of vehicles that will be using it. The fact that the same road and rail facilities are also being utilised by both passengers and freight transport compounds the problem. It was suggested that the potential connections offered by the rail network between UK airports could be utilised to reduce the volume of road haulage traffic. Improving rail services and maximising utilisation, so that all freight vehicles are full to capacity when entering and exiting the airport, could also provide additional support. There is already extensive road and rail connectivity, namely, the Heathrow Express, Heathrow Connect, the Underground, buses, and coaches. Currently, the Elizabeth line and High Speed Two (HS2) are also being constructed and may provide suitable options for the transport of air freight from LHR. Consequently, careful thought needs to be given to the planning and cohesiveness of the LHR expansion in order to address the potential increased demands on the existing rail and road capacity.

Despite the claim by Behrend et al. (2008) [37] that an integrated approach involving all actors involved could be used to overcome the challenges that exist within the freight 
industry, the findings did not emphasise collaboration between stakeholders as a recommendation. This could be due to the fact that measures that are deemed ideal for mitigating a challenge in theory may be constrained in real life. However, there is an opportunity to improve resilience. Although competition was identified as a significant challenge, the participants suggested no potential mitigation measure for it. It may simply be the case that competition is an unavoidable phenomenon within all market sectors, including the freight industry. The contemporary mitigation measures put forward encompassed the use of Electric Vehicles (EV) technology by companies, smart scheduling systems for faster responsiveness, and optimal travel distances, as well as land value capture mechanisms.

The measures that were suggested to mitigate the effects on nearby communities were also relevant to combating the direct adverse impacts on the freight industry. For instance, congestion was a common challenge faced by both the community and the freight industry. The implementation of cargo-only roads could reduce traffic congestion, while cleaner vehicles and restrictions on engine idling would mitigate air pollution $[32,33]$ as part of the UK's Government actions against the effects of climate change. From an optimistic point of view, the negative implications could be minimised through appropriate coordination in terms of planning and ICT, which may also strengthen the positive implications.

\section{Conclusions}

This research has critically explored and discussed the implications of the LHR expansion for the landside freight industry. It has highlighted the present synergies between airports, surface access, and the landside freight industry, which are relevant to the LHR expansion project. It has also given an indication of what to expect and clearly the LHR expansion would increase air cargo, which will in turn affect its land freight counterpart. These findings are in accordance with the existing research.

The study also provided new information on the ratings for the key implications resulting from the LHR expansion, which may assist local authorities with their future planning, encouraging them to prioritise building and improving resilience to adversity. Increased freight activities and employment stood out as the key positive implications, while increased delays due to congestion constituted the predominant negative implication for the landside freight industry. The direct negative implications that affected freight companies varied from operating costs, competition, capacity, and congestion related issues to legislative challenges. Accordingly, the induced implications for local communities were associated with spinoff challenges, namely, social, environmental, and road safety challenges. The aforementioned challenges faced by communities could bolster or hinder the longevity of the industry. Meanwhile, potential measures suggested that mitigating the adverse effects of the LHR expansion included the use of intelligent booking systems and smart scheduling to revise the timetabling of deliveries, reinforcing consolidation centre efforts, collaboration between freight companies, use of low carbon technologies, and the increased use of rail transport for air cargo. These methods are understood to significantly improve efficiency and reduce idle time, which should be beneficial to the land side freight industry.

In terms of the policy implications, several airport-related policy safeguards were revealed. Policies regarding air quality, surface access, connectivity, and noise should be strengthened to build greater resilience to the challenges resulting from airport expansion. In addition, in the case of LHR, airport-related infrastructure policies are strongly advocated to address the division between rail and road freight and passenger versus freight transport (non-passenger movement). Therefore, the findings could help policy makers and planners better understand the potential opportunities and challenges regarding the LHR expansion, from which suitable interventions could be developed to reduce the negative impacts in order to stimulate Britain's future economic growth. Overall, the results show that the positive implications of the airport expansion could outweigh the negatives, and therefore, proceeding with the expansion is highly recommended given that appropriate mitigation measures can be put in place. 
The main limitation of this study is the interviewee sample size, given that there were only twelve participants. The limited number of interviewees could slightly affect the generalisability of the findings to other airports.

Author Contributions: Conceptualisation, R.L., M.S., and M.C.; methodology, R.L. and M.C.; software, R.L.; validation, J.A., X.G. and T.Y.; formal analysis, R.L. and M.C.; investigation, R.L.; resources, R.L., M.S. and J.A.; data curation, R.L.; writing—original draft preparation, R.L., M.S. and M.C.; writing-review and editing, J.A., X.G. and T.Y.; supervision, M.C.; funding acquisition, J.A. and M.C. All authors have read and agreed to the published version of the manuscript.

Funding: The authors would like to gratefully acknowledge the EPSRC for funding this work through its financial support of The Centre for Sustainable Road Freight (EPSRC Reference: EP/R035148/1). This research is also partly funded by the NSFC (Project No. 51808392), the SCUE Research Fund, and School Funding from the University of Westminster.

Institutional Review Board Statement: The study was conducted according to the guidelines of the University of Westminster, and approved by the Ethics Committee of University of Westminster (date of approval: July 2018).

Informed Consent Statement: Written informed consent has been obtained from the participant(s) to publish this paper.

Data Availability Statement: Not applicable.

Acknowledgments: The authors would like to thank Maja Piecyk, the editor, and anonymous reviewers for their valuable comments on the initial draft of this paper. We would also like to gratefully acknowledge the EPSRC for funding this work through its financial support of The Centre for Sustainable Road Freight (EPSRC Reference: EP/R035148/1). This research is also partly funded by the NSFC (Project No. 51808392), the SCUE Research Fund, and School Funding from the University of Westminster.

Conflicts of Interest: The authors declare no conflict of interest.

\section{References}

1. International Airport Review. Heathrow Airport Responds to Supreme Court Ruling for Third Runway. 2020. Available online: https: / / www.internationalairportreview.com/news/147146/supreme-court-gives-heathrow-airports-third-runwaythe-green-light/ (accessed on 16 December 2020).

2. Heathrow Airport Limited. Heathrow Expansion-Our Approach to Developing a Surface Access Strategy. 2018. Available online: https:/ / www.heathrowconsultation.com/wp-content/uploads/2018/01/6747-Expansion-Surface-Access-v7-72dpi.pdf (accessed on 26 February 2018).

3. Hesse, M.; Rodrigue, J.-P. The transport geography of logistics and freight distribution. J. Transp. Geogr. 2004, 12, 171-184. [CrossRef]

4. Heathrow Airport Limited. Sustainable Transport Plan 2014-2019. 2014. Available online: https://www.heathrow.com/file_ source/Company/Static/PDF/Heathrow_STP_inter.pdf (accessed on 15 January 2018).

5. Airports Council International. ACI Reveals Top 20 Airports for Passenger Traffic, Cargo, and Aircraft Movements. 2020. Available online: https:/ / aci.aero/news/2020/05/19/aci-reveals-top-20-airports-for-passenger-traffic-cargo-and-aircraft-movements / (accessed on 24 June 2021).

6. Budd, L.; Ison, S. Air Transport Management: An International Perspective, 2nd ed.; Routledge: Abingdon, UK, 2020.

7. Heathrow Airport Limited. Heathrow Expansion: Building for the Future. 2018. Available online: https://www. heathrowexpansion.com/the-expansion-plan/ (accessed on 3 February 2018).

8. Dewulf, W.; Meersman, H.; Van de Voorde, E. The Strategy of Air Cargo Operators: About Carpet Sellers and Cargo Stars; Airline Economics in Europe (Advances in Airline Economics); Emerald Publishing Limited: Bingley, UK, 2019; Volume 8, pp. 167-199.

9. Kupfer, F.; Kessels, R.; Goos, P.; Van de Voorde, E.; Verhetsel, A. The origin-destination airport choice for all-cargo aircraft operations in Europe. Transp. Res. Part E Logist. Transp. Rev. 2016, 87, 53-74. [CrossRef]

10. Wensveen, J. Air Transportation A Management Perspective, 8th ed.; Ashgate Publishing Ltd: New York, NY, USA, 2015.

11. Golicic, S.; McCarthy, T.; Mentzer, J. Conducting a market opportunity analysis for air cargo operations. Transp. J. 2003, 42, 5-15. [CrossRef]

12. Gritschke, R. Cargo terminal and warehouse design-If cargo moves faster, do the facilities have to change? In Proceedings of the ACI World Air Cargo Conference, Sharjah, United Arab Emirates, 8-11 March 1999.

13. Department of the Environment, Transport and the Regions (DETR). UK Airfreight Study Report; Department of the Environment, Transport and the Regions: London, UK, 2000. 
14. Manchester Airport. A Guide to Manchester Airport World Freight Terminal; British Publishing Company: Manchester, UK, 2000.

15. Budd, T.; Ison, S.; Ryley, T. Airport surface access in the UK: A management perspective. Res. Transp. Bus. Manag. 2011, 1, 109-117. [CrossRef]

16. Hoare, A. International airports as growth poles: A case study of Heathrow Airport. Transp. Inst. Br. Geogr. 1974, 63, 75-96. [CrossRef]

17. Booz-Allen and Hamilton. Regions to London and London's Airports Study, Report for the Strategic Rail Authority. 2000. Available online: http://www.aerohabitat.eu/uploads/media/12-12-2000_-_Booz_-_Allen_-_Hamilton_-_London_s_apts_ Study_150_KB_.pdf (accessed on 20 December 2017).

18. Colin Buchanan and Partners. Heathrow Economics Study: Expansion of Heathrow Airport. 2006. Available online: https: //www.london.gov.uk/sites/default/files/gla_migrate_files_destination/heathrow-economics-study-nov06.pdf (accessed on 31 December 2017).

19. Hopper, A. London's Insufficient Airport Capacity: Why is it a Recurring Problem? 2013. Available online: http: / / ardent.mit.edu/airports / ASP_exercises / ASP\%202013\%20reports\%20for\%20posting/ASP\%20Hopper\%20London\%27 s\%20Insufficient\%20Capacity\%20Report.pdf (accessed on 12 December 2017).

20. Griggs, S.; Howarth, D. Between a rock and a hard place: The coalition, the davies commission and the wicked issue of airport expansion. Polit. Q. 2013, 84, 515-526. [CrossRef]

21. York Aviation. Final Report: Implications for the Air Freight Sector of Different Airport Capacity Options. 2015. Available online: http:/ / content.tfl.gov.uk/air-freight-implications-from-new-capacity.pdf (accessed on 21 May 2018).

22. Young, S.; Wells, A. Airport Planning and Management, 6th ed.; McGraw-Hill: New York, NY, USA, 2011.

23. Graham, A. Managing Airports: An International Perspective, 4th ed.; Routledge: Abingdon, UK, 2014.

24. Emery, J. The freight forwarder and the development of air freight. Law Contemp. Probl. 1950, 15, 29-36. [CrossRef]

25. Janic, M. Expansion of airport capacity at London Heathrow airport. SAGE J. 2004, 1888, 7-14. [CrossRef]

26. Pellegrini, P.; Bolić, T.; Castelli, L.; Pesenti, R. SOSTA: An effective model for the simultaneous optimisation of airport slot allocation. Transp. Res. Part E Logist. Transp. Rev. 2017, 99, 34-53. [CrossRef]

27. Sentance, A. Airport slot auctions: Desirable or feasible? Util. Policy 2003, 11, 53-57. [CrossRef]

28. Smit, H.T.J. Infrastructure Investment as a real options game: The case of European airport expansion. Financ. Manag. 2003, 32, 27-57. [CrossRef]

29. Sankaran, J. Freight logistics in the New Zealand context. Int. J. Phys. Distrib. Logist. Manag. 2000, 30, 145-164. [CrossRef]

30. Gardiner, S.; Humphreys, I.; Ison, S. Freighter operators' choice of airport: A three-stage process. Transp. Rev. 2005, 25, 85-102. [CrossRef]

31. Liimatainen, H.; Hovi, I.B.; Arvidsson, N.; Nykänen, L. Driving forces of road freight $\mathrm{CO}_{2}$ in 2030. Int. J. Phys. Distrib. Logist. Manag. 2015, 45, 260-285. [CrossRef]

32. Cao, M.; Chen, C.-L.; Hickman, R. Transport emissions in Beijing: A scenario planning approach. Proc. Inst. Civ. Eng. Transp. 2017, 170, 65-75. [CrossRef]

33. Shammut, M.; Cao, M.; Zhang, Y.; Papaix, C.; Liu, Y.; Gao, X. Banning diesel vehicles in London: Is 2040 too late? Energies 2019, 12, 3495. [CrossRef]

34. Ashford, N.; Stanton, M.; Moore, C. Airport Operations, 2nd ed.; McGraw Hill: New York, NY, USA, 1997.

35. Humphreys, I.; Ison, S.; Francis, G.; Aldridge, K. UK airport surface access targets. J. Air Transp. Manag. 2005, 11, 117-124. [CrossRef]

36. Department for Transport (DfT). UK Air Passenger Demand and CO2 Forecasts; TSO: London, UK, 2009.

37. Behrends, S.; Lindholm, M.; Woxenius, J. The impact of urban freight transport: A definition of sustainability from an actor's. Transp. Plan. Technol. 2008, 31, 693-713. [CrossRef]

38. Browne, M.; Sweet, M.; Woodburn, A.; Allen, J. Urban Freight Consolidation Centres, Final Report; Transport Studies Group, University of Westminster: London, UK, 2005.

39. Davies, A.; Gann, D.; Douglas, T. Innovation in megaprojects: Systems integration at London Heathrow Terminal 5. CA Manag. Rev. 2009, 51, 101-125. [CrossRef]

40. Olsson, J.; Woxenius, J. Localisation of freight consolidation centres serving small road hauliers in a wider urban area: Barriers for more efficient freight deliveries in Gothenburg. J. Trans. Geogr. 2014, 34, 25-33. [CrossRef]

41. Zhou, G.; Hui, Y.V.; Liang, L. Strategic alliance in freight consolidation. Transp. Res. Part E Logist. Transp. Rev. 2011, 47, 18-29. [CrossRef]

42. Nguyen, C.; Dessouky, M.; Toriello, A. Consolidation strategies for the delivery of perishable products. Transp. Res. Part E Logist. Transp. Rev. 2014, 69, 108-121. [CrossRef]

43. Ali, S.S.; Kaur, R.; Marmolejo Saucedo, J.A. Research implications in supply chain management. In Best Practices in Green Supply Chain Management; Emerald Publishing Limited: Bradford, UK, 2019; pp. 17-36.

44. Huo, B.; Guo, M. How does an aerotropolis integrate? A case from Zhengzhou airport economy zone. Logistics 2021, 5, 26. [CrossRef]

45. Zhu, Q.; Krikke, H.; Caniëls, M.C.J. The effects of different supply chain integration strategies on disruption recovery: A system dynamics study on the cheese industry. Logistics 2021, 5, 19. [CrossRef]

46. Freight Transport Association. FTA Logistics Report 2018; Freight Transport Association: Tunbridge Wells, UK, 2018. 
47. Behiri, W.; Belmokhtar-Berraf, S.; Chu, C. Urban freight transport using passenger rail network: Scientific issues and quantitative analysis. Transp. Res. Part E Logist. Transp. Rev. 2018, 115, 227-245. [CrossRef]

48. Tang, C.S.; Veelenturf, L.P. The strategic role of logistics in the industry 4.0 era. Transp. Res. Part E Logist. Transp. Rev. 2019, 129, 1-11. [CrossRef]

49. Gurtu, A.; Johny, J. Potential of blockchain technology in supply chain management: A literature review. Int. J. Phys. Distrib. Logist. Manag. 2019, 49, 881-900. [CrossRef]

50. Choi, T.-M.; Wen, X.; Sun, X.; Chung, S.-H. The mean-variance approach for global supply chain risk analysis with air logistics in the blockchain technology era. Transp. Res. Part E Logist. Transp. Rev. 2019, 127, 178-191. [CrossRef]

51. Xu, P.; Lee, J.; Barth, J.R.; Richey, R.G. Blockchain as supply chain technology: Considering transparency and security. Int. J. Phys. Distrib. Logist. Manag. 2021, 51, 305-324. [CrossRef]

52. Meidute-Kavaliauskiene, I.; Yıldız, B.; Çiğdem, Ş.; Činčikaitè, R. An integrated impact of blockchain on supply chain applications. Logistics 2021, 5, 33. [CrossRef]

53. Heathrow Airport Limited. Our Cargo Strategy-Timely, Reliable and Easy to do Business With. 2017. Available online: https:/ / www.heathrow.com/content/dam/heathrow/web/common/documents/company/cargo/caro-strategy.pdf (accessed on 30 May 2018).

54. Civil Aviation Authority. Aircraft and Passenger Traffic Data for UK Airports. 2020. Available online: https://www.caa.co.uk/ Data-and-analysis/UK-aviation-market/Airports/Datasets/ (accessed on 30 April 2020).

55. Kelley, K.; Clark, B.; Brown, V.; Sitzia, J. Good practice in the conduct and reporting of survey research. Int. J. Qual. Health Care 2003, 15, 261-266. [CrossRef] [PubMed]

56. Bryman, A. Social Research Methods, 4th ed.; Oxford University Press: Oxford, UK, 2014.

57. Li, S.; Zhao, P. Restrained mobility in a high-accessible and migrant-rich area in downtown Beijing. Eur. Transp. Res. Rev. 2018, 10, 4. [CrossRef]

58. Civil Aviation Authority. Requirements for Ground Handling and Cargo Agents-Guidance and Training Related to Dangerous Goods. 2021. Available online: https://www.caa.co.uk/Commercial-industry/Airports/Safety/Dangerous-goods/ Requirements-for-ground-handling-and-cargo-agents / (accessed on 23 June 2020).

59. McKinnon, A.; Browne, M.; Whiteing, A.; Piecyk, M. Green Logistics: Improving the Environmental Sustainability of Logistics, 3rd ed.; Kogan Page: London, UK, 2015.

60. Dennis, N. Airline hub operations in Europe. J. Transp. Geogr. 1994, 2, 219-233. [CrossRef]

61. Yuan, X.-M.; Low, J.M.; Tang, L.C. Roles of the airport and logistics services on the economic outcomes of an air cargo supply chain. Int. J. Prod. Econ. 2010, 127, 215-225. [CrossRef] 